ISSN 1997-5902

\title{
Oyster mushroom (Pleurotus spp.) cultivation technique using re-usable substrate containers and comparison of mineral contents with common leafy vegetables
}

\author{
Delphina P. Mamiro*, Peter S. Mamiro, Maulid W. Mwatawala \\ Sokoine University of Agriculture, P. O. Box 3005, Morogoro, Tanzania \\ *Corresponding author's e-mail: delphimamiro@yahoo.com
}

Original submitted in on $6^{\text {th }}$ June 2014. Published online at www.m.elewa.org on $31^{\text {st }}$ August 2014. http://dx.doi.org/10.4314/jab.v80i1.13

\begin{abstract}
Alternative re-usable substrate containers for fructification are required because plastic bags currently used suffocate soil biotic entities. They are a cost for mushroom farmers who purchase plastic bags in every oyster mushroom crop and they are left as non-biodegradable wastes, which are disposed of to the environment after every oyster mushroom cropping. On the other hand, oyster mushroom contains essential nutritional elements comparable to leafy vegetables.

Objectives: The objectives of this study were to determine the effects of substrate types and substrate containers on yield, biological efficiency, size and solid content of oyster mushroom Pleurotus ostreatus; and to compare mineral content of mushrooms produced from different types of substrates to common leafy vegetables.

Methodology and results: Substrate containers: clear plastic bags, re-usable substrate containers (RSC), coloured plastic bags, shelved clear plastic bags and substrates: banana leaves, rice straws and maize cobs were used to grow oyster mushrooms. The experiment was carried out in complete randomized block design (CRBD) in a factorial arrangement. The mineral content of oyster mushroom grown on rice straws, Leucaena leucocophala, sorghum grains, banana leaves and maize cobs substrates were compared in a CRBD to those of pumpkin leaves (Curcubita spp.), narrow-leaved African night shade (Solanum villosum), broad-leaved African night shade (Solanum scabrum), cowpea leaves (Vigna unguiculata), cabbage (Brassica spp.), sweet potato leaves (Ipomea batatas), amaranth (Amaranthus spp.) and cassava leaves (Manihot esculentus L.). Mushroom yields and BE in RSC were comparable to non-RSC. The highest yields $(1,116.25 \mathrm{~g} / \mathrm{g})$ and $\mathrm{BE}(105.75 \%)$ were produced from rice straws substrate in coloured bags followed by RSC (yield $694.6 \mathrm{~g} / \mathrm{g}, \mathrm{BE} 65.6 \%$ ). Mushroom solids content (19.4\%) was highest from banana leaves substrates. The highest $\mathrm{Fe}, \mathrm{Zn}, \mathrm{Se}$ and $\mathrm{Ca}$ were obtained from amaranth, oyster mushrooms produced from rice straws, narrow- and broad-leaves African nightshade and pumpkin leaves respectively. Conclusion and application of results: The utilization of RSC to produce oyster mushrooms protects the environment from disposed plastic bags which are non-biodegradable and if burned may cause ill-health effect to the human. Additional research is needed to specify quality of material to be used in the manufacture of RSC and specifications to suit cultivation of oyster mushrooms. In addition, consumption of oyster mushrooms in combination with other vegetables complements availability of various essential dietary elements such as $\mathrm{Fe}, \mathrm{Zn}$, Se and $\mathrm{Ca}$.
\end{abstract}

Key words: biological efficiency, mushroom yield, mushroom size, mushroom solids content 

usable substrate containers and comparison of mineral content with leafy vegetables.

\section{INTRODUCTION}

Cultivation of oyster mushrooms (Pleurotus spp.) was initiated in Germany in 1917 on tree stumps and wood logs (Upadhyay, 2010). Since then growing technologies (Chang \& Miles, 1989; FAO, 1990;) have been improved and vary considerably around the world. Like other mushrooms, Pleurotus spp. can be grown on various crop residues with the use of different substrate containers (Bisaria et al., 1989). Some substrate containers are such as plastic tubs and trays of various descriptions for Agaricus bisporus, open straw bales and plastic bags and bottles for Pleurotus spp. Suitable substrate containers for Pleurotus spp. should have the following properties:

- It should enclose substrate during the spawn run;

- It should not allow the light to the spawned substrate to avoid initiation of mushroom primordial in inaccessible places;

- It should not break or puncture easily during handling;

- It should not allow excessive loss of moisture; it should avoid excessive selfheating and

- It should allow the maximum production in the space used for production of oyster mushrooms.

Currently, in the developing countries, oyster mushrooms (Pleurotus spp.) are produced by using plastic bags as substrate containers for fructification. Type of plastic bags used are made out of polyethylene (for pasteurized substrates), polypropylene or polyvinyl chloride (for sterilized substrate) (Oei, 2003; Mushworld, 2004). After harvest of oyster mushrooms the waste substrate containers are most often burnt. While some farmers' burn plastic wastes after removal of spent mushroom compost (SMC) from the mushroom

\section{MATERIALS AND METHODS}

Determining the effects of substrate types and substrate containers on yield, biological efficiency, size and solid content of oyster mushroom: The primary inoculum was prepared from the fresh fruiting growing rooms, others pile them near mushroom growing houses and become source of nonbiodegradable solid wastes and breeding places for mosquitoes especially in the tropics. If polyvinyl chloride is burned at temperature below $600^{\circ} \mathrm{C}$, it forms dioxins, which are extremely toxic substance (Andersen \& Knapp, 1993; Alcock \& Jones, 1996; Thorntom, 1997). Plastic bags should be removed before the SMC is applied to the soil, but quite often, the oyster mushroom producers do not know the importance of this practice (Oei, 2003; Mushworld, 2004). Plastic bags suffocate soil biotic entities and are used only once, hence a cost for mushroom farmer to purchase plastic bags in every mushroom crop. Alternative re-usable substrate containers such as plastic tubs and clay pots for fructification may be utilized. Alternative re-usable substrate containers for fructification in the cultivation of Pleurotus spp. would both conserve the environment and save money for mushroom grower to which otherwise would be used purchase plastic bags at every oyster mushroom spawning time. Very few studies have used re-usable substrate containers in the production of Pleurotus spp. King Oyster (Pleurotus eryngii (DC.) Qul) has been produced by using re-usable plastic bottles (RodriguesEstrada, 2008). The information thus obtained from this study would be relevant for oyster mushroom producers for cleaner environment and cost reduction of purchasing plastic bags every oyster mushroom cropping. Thus, the present work was carried out with an objective of testing alternative substrate containers to plastic bags for fructification in oyster mushrooms [Pleurotus ostreatus (Jacq. Ex. Fr.) Kumar] production in small-scale farming and comparison of mushroom minerals with those from leafy vegetables.

bodies of the oyster mushroom through tissue culture method and was maintained and multiplied by subculturing on sterilized potato dextrose yeast extract agar medium in Petri dishes incubated at room 
Mamiro et al. J. Appl. Biosci. 2014. Oyster mushroom (Pleurotus spp.) Cultivation technique using reusable substrate containers and comparison of mineral content with leafy vegetables.

temperature $\left(28 \pm 2^{\circ} \mathrm{C}\right)$. Spawn was prepared as described by Mamiro \& Mamiro (2011) whereby $750 \mathrm{ml}$ of tap water was added to $500 \mathrm{~g}$ of white sorghum (Sorghii bicolor L.) grains in 1000 ml-beaker and allowed to soak for $3 \mathrm{~h}$. Two hundred grams (w/w) of soaked grains were placed in $350 \mathrm{ml}$ bottles, caped and autoclaved at $12^{\circ} \mathrm{C}$ for $20 \mathrm{~min}$. The sorghum grains were allowed to cool over night before inoculation with
$0.5 \mathrm{~mm}$ diameter $P$. ostreatus culture under aseptic conditions. Inoculated sorghum grains were placed on a laboratory bench at room temperature $\left(29 \pm 2^{\circ} \mathrm{C}\right)$, and shaken after every 2-4 days, depending on rate of mycelial growth to enhance uniform growth. The mature sorghum spawn was stored at $5^{\circ} \mathrm{C}$ until use. Two oyster mushroom cropping trials were conducted at Sokoine University of Agriculture.
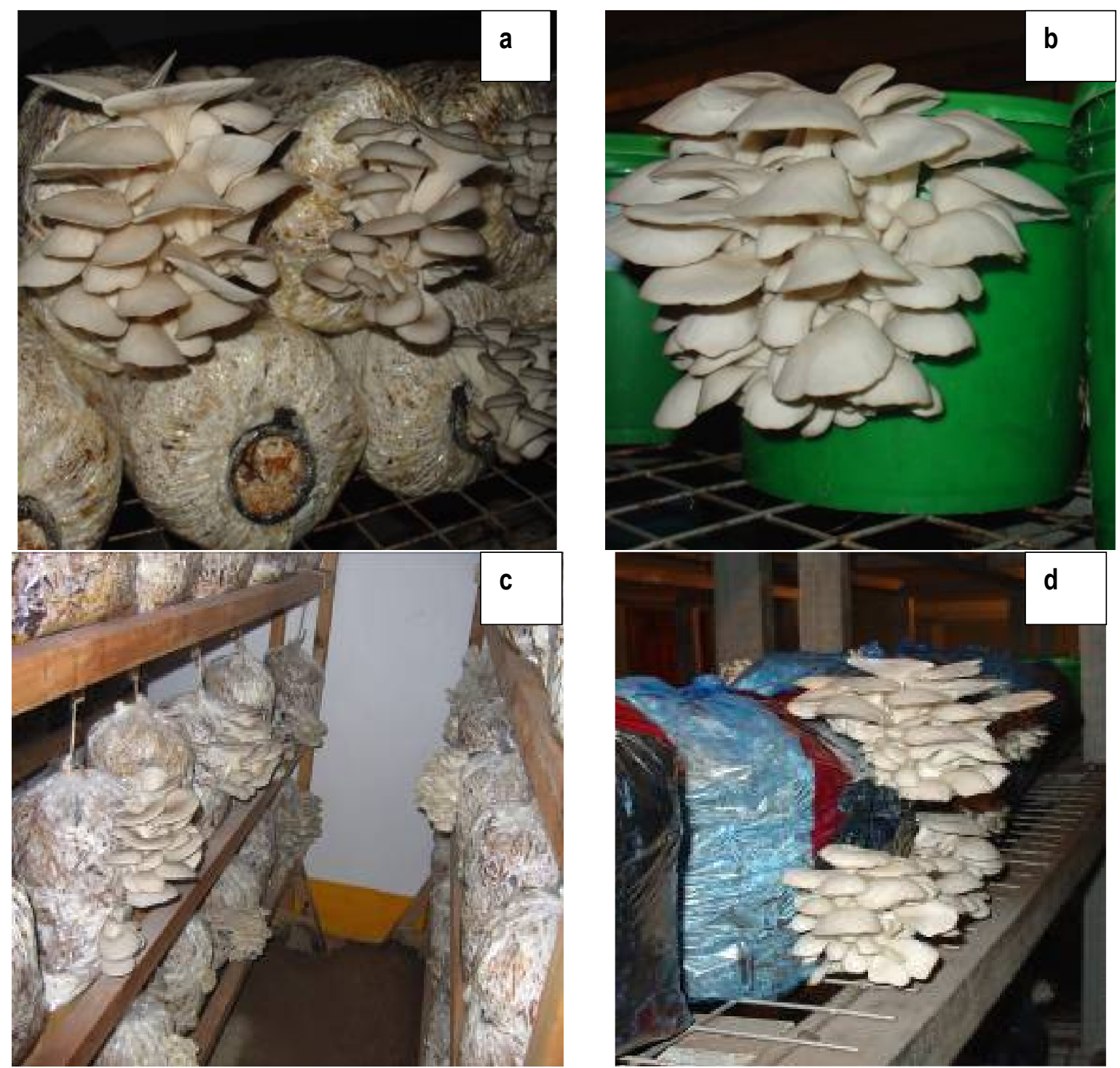

Figure 1: Production of $P$. ostreatus in various substrate containers (a) Clear bags - vipete in Kiswahili, (b) Reusable substrate containers- visado in Kiswahili, (c) Hanging clear plastic bags and (d) coloured plastic bags as substrate containers - rambo in Kiswahili

Known weight of hand-chopped substrates were soaked overnight; allow draining to until no water was dripping from them when hand squeezed. They were placed in the respective containers, steam pasteurized at $98^{\circ} \mathrm{C}$ for $4 \mathrm{~h}$, aseptically cooled and spawned with 40 $\mathrm{g}$ spawn per $3 \mathrm{~kg}$ substrate $(1.3 \%$, w/w). After spawning, the bags were placed in dark room for spawn run $\left(28-30^{\circ} \mathrm{C}, 20-25\right.$ days). The substrate 
Mamiro et al. J. Appl. Biosci. 2014. Oyster mushroom (Pleurotus spp.) Cultivation technique using reusable substrate containers and comparison of mineral content with leafy vegetables.

containers were placed in light room. 'Light hold' (a time between lighting and mushroom primordial formation) lasted for $20-25$ days at $28-30^{\circ} \mathrm{C}$; during this period tap water was applied daily or as needed and misting the air with knap sack sprayer. Relative humidity in the production room was kept at $85-95 \%$. The first oyster mushroom cropping experiment treatments were arranged in factorial in complete randomised block design (CRBD) with four replications. There were two sources of variation; substrate type viz: rice straws

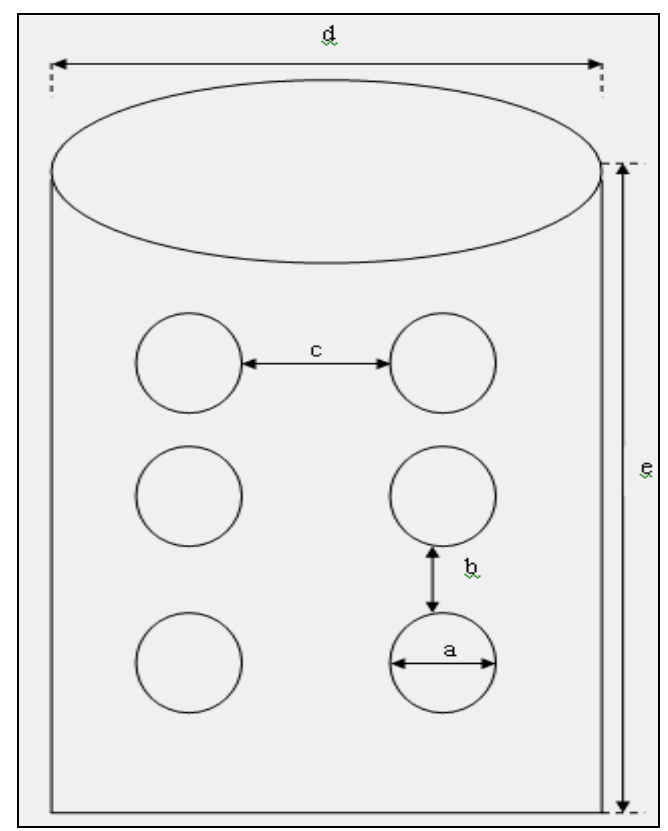

(Oryza sativa L.), banana leaves (Musa spp.) and maize cobs (Zea mays L.) while substrate containers were: shelved-clear plastic bags: height $47.5 \mathrm{~cm}$, length $25.3 \mathrm{~cm}$ (Fig. 1a); re-usable substrate containers (RSC): height $18.8 \mathrm{~cm}$, diameter $19.0 \mathrm{~cm}$ (Fig. 1b and 2); hanging clear plastic bags - height $20.0 \mathrm{~cm}$, diameter $15.0 \mathrm{~cm}$ (Fig. 1C) and coloured plastic bags height $59.0 \mathrm{~cm}$, length $27.0 \mathrm{~cm}$ known as "rambo" (Fig. 1d).

Figure 2: Specifications of re-usable substrate containers: $a=0.5 \mathrm{~cm}, b=3.5-4.0 \mathrm{~cm}, c=5.0 \mathrm{~cm}, \mathrm{~d}=19.0 \mathrm{~cm}$

Re-usable substrate containers were 5 - L solid plastic bucket-like and they contained lids. They were modified by making a total of 6 holes on the side-surface (two rows of three-holes each) to allow pin head emergence. The holes $(0.5 \mathrm{~cm}$ diameter) were made by piercing the side surface of container by red-hot nail; each side had 6 holes and the distances between holes were 3.5-4.0 $\mathrm{cm}$. Five different types of substrates were used in the second oyster mushroom cropping experiment in CRBD with four replications. The substrates used to produce oyster mushrooms were rice straws, banana leaves, maize cobs, Leucaena leucocophala leaves and sorghum (Sorghi bicolor L.) grains. All substrates used in both crops were fresh and dry. Only shelvedclear plastic bags (height $47.5 \mathrm{~cm}$, length $25.3 \mathrm{~cm}$ ) were used as substrate containers because mushrooms harvested from this experiment were used only in the analysis of mineral content. All substrate containers were purchased and modified accordingly to suit oyster mushroom fructification requirement. Substrates initial moisture content was determined by constant-temperature oven method. Hundred grams of each chopped substrates were placed in a metal container, replicated 4 times and oven-dried at $60^{\circ} \mathrm{C}$ for $24 \mathrm{~h}$. All substrates were allowed to cool in the desiccators and the moisture content and percentage by weight was calculated as

Loss of weight / initial weight x 100 .

Oyster mushrooms were harvested when the lamellae were fully exposed. Mushrooms were harvested, counted and weighed daily for three flushes. Mushroom yield and $\mathrm{BE}$ were determined and average mushroom size was calculated as fresh mushrooms harvested divided by the number of mushrooms per substrate container. Biological efficiency was determined as the ratio of fresh mushrooms harvested $(\mathrm{g})$ per gram of dry substrate and expressed as a percentage. Yield was the weight of the mushrooms harvested per unit 
Mamiro et al. J. Appl. Biosci. 2014. Oyster mushroom (Pleurotus spp.) Cultivation technique using reusable substrate containers and comparison of mineral content with leafy vegetables.

production weight of dry substrates and was expressed as $\mathrm{g} / \mathrm{g}$. Fresh oyster mushrooms for solids content determination were randomly sampled from each treatment (regardless of block) and were sliced into quarters and eighths depending on the original mushroom size. Samples $(100 \mathrm{~g})$ were placed in a paper bag and oven dried at $60^{\circ} \mathrm{C}$ for $48 \mathrm{~h}$. Dried oyster mushrooms were placed in the desiccators to cool before weighing. The general linear model (SAS, 2001) procedure was used for analysis of variance. Treatment means were separated according to Fisher's Least Significant Difference test $(p<0.05)$ (Kuehl, 2000).

Comparison mineral contents of oyster mushroom to commonly used leafy vegetables: The trial was conducted in a complete randomised design, replicated three times to analyse the mineral quantity of eight leafy vegetable types and oyster mushrooms produced from different five different types of substrates. The leafy vegetables were pumpkin (Curcubita spp.),

\section{RESULTS}

Effect of substrate type and containers on yield, $B E$, size and solid content of oyster mushroom: Results show that there were significant differences on the interaction of substrate types and substrate narrow-leaved African nightshade (Solanum villosum), broad-leaved African nightshade (Solanum scabrum), cowpea (Vigna unguiculata L.), cabbage (Brassica spp.), sweet potato (Ipomea batatas), amaranth (Amaranthus spp.) and cassava (Manihot esculentus L.). All vegetables were purchased from local market in Morogoro town. Mineral quantity of the samples of oyster mushrooms harvested from five different substrates (viz. and 8 common leafy vegetables obtained from local market was carried out after dry ash. The ash was dissolved in a solution of 1:1 ratio of water:hydrochloric acid $\left(\mathrm{H}_{2} \mathrm{O}: \mathrm{HCl}\right)$, in which the concentration of the final mixture was 6 Normality of Hydrochloric acid $(6 \mathrm{~N} \mathrm{HCl})$. To equate normality to molarity, $6 \mathrm{~N}=6 \mathrm{~mol} / 1 \mathrm{~L}$ of Hydrochloric acid. Total iron, zinc, selenium and calcium were determined by atomic absorption spectrophotometer by AOAC method (AOAC, 1995). Data for each mineral type were subjected to one-way ANOVA.

containers on mushroom yield ( $p \leq 0.05, n=96, d f=80$, Fisher's $L S D=0.1121$ ) as indicated in Figure 3 and $B E$ ( $\mathrm{p} \leq 0.05, \mathrm{n}=96, \mathrm{df}=80$, Fisher's LSD $=9.7198$ ) as shown in Figure 4.

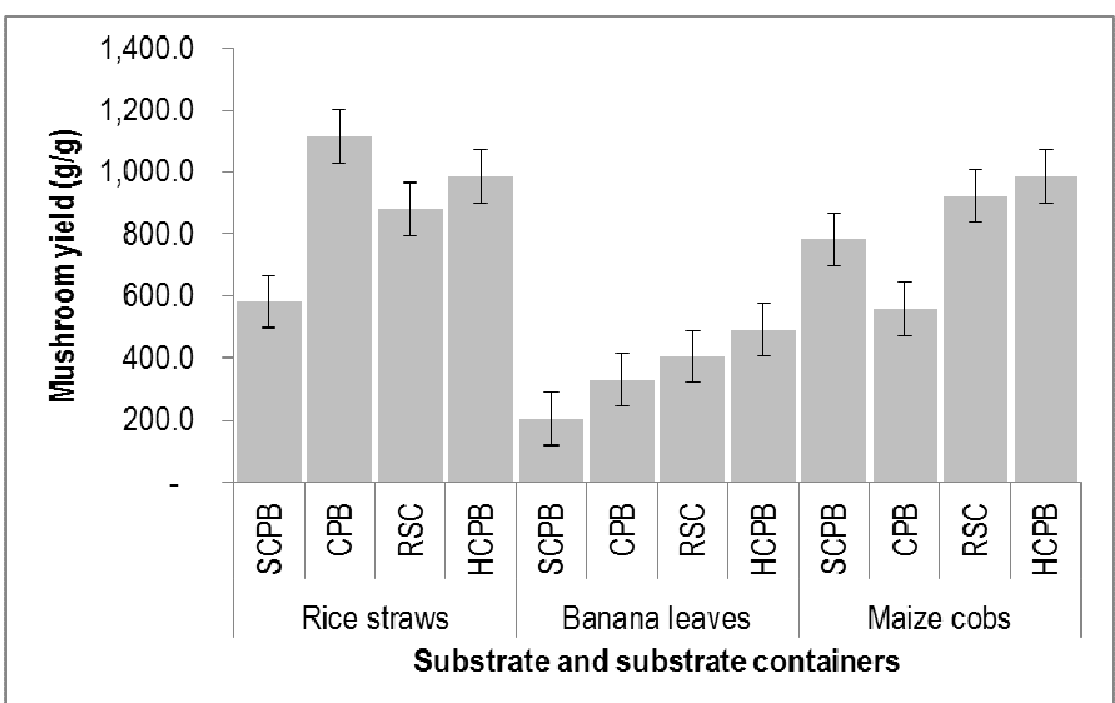

Figure 3: Effect of treatments (substrates $X$ substrate containers [SCPB=shelved clear plastic bags, $C P B=$ coloured plastic bags, RSC=re-usable substrate containers, $\mathrm{HCPB}=$ hanging clear plastic bags]) combination on yield of $P$. ostreatus ( $p \leq 0.05, n=96, d f=80$, Fisher's LSD $=0.1121$ ) 


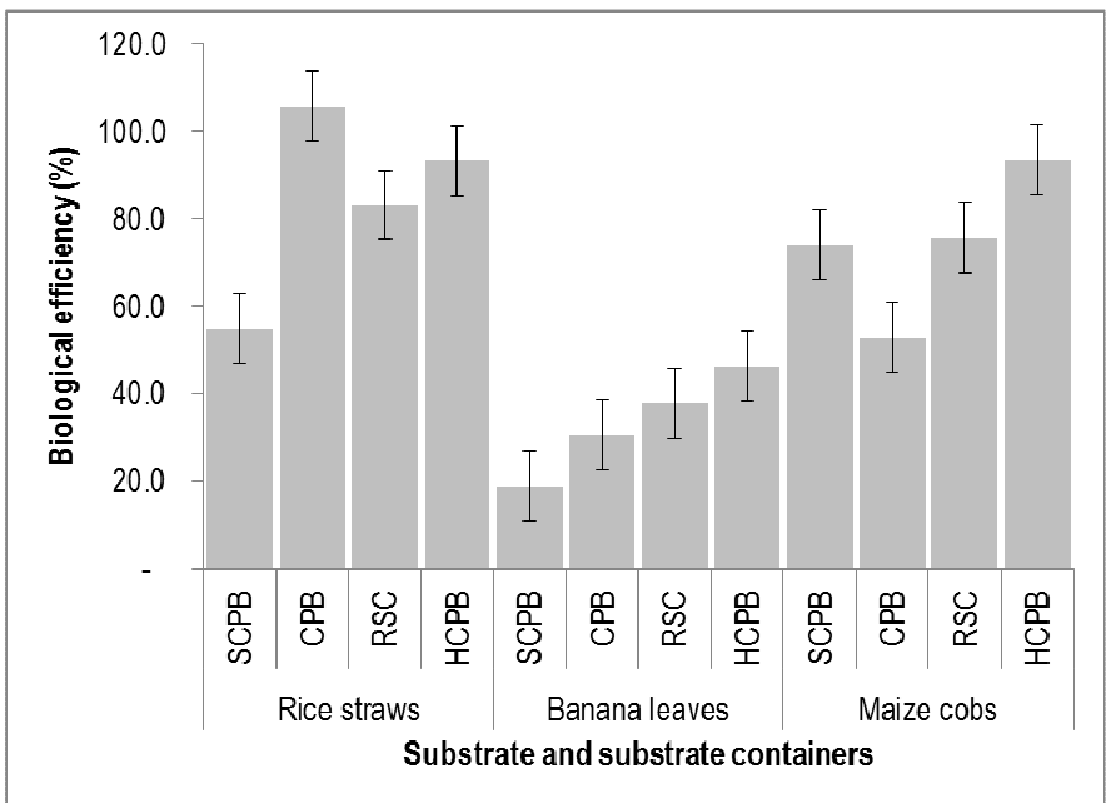

Figure 4: Effect of treatments (substrates $X$ substrate containers [SCPB=shelved clear plastic bags, $C P B=$ coloured plastic bags, RSC=re-usable substrate containers, $\mathrm{HCPB}=$ hanging clear plastic bags]) combination on biological efficiency of $P$. ostreatus ( $p \leq 0.005, \mathrm{n}=96, \mathrm{df}=80$, Fisher's $L S D=9.7198) . \mathrm{BE}=(\mathrm{g}$ fresh mushrooms $/ \mathrm{g}$ dry substrate) $\mathrm{x}$ 100.

Yields $(1,116.25 \mathrm{~g} / \mathrm{g})$ and $\mathrm{BE}(105.75 \%)$ were highest in the interaction between rice straws substrate and coloured plastic bags substrate containers (Figures 3 and 4). For substrate containers, the highest mushroom yields $(821.67 \mathrm{~g} / \mathrm{g})$ and $\mathrm{BE}(77.71 \%)$ were obtained from hanging clear plastic bags (Table 1). However, yields and $\mathrm{BE}$ from hanging clear plastic bags (821.67 $\mathrm{g} / \mathrm{g}, 77.71 \%$ ) were not significantly higher than those from RSC (694.58 $\mathrm{g} / \mathrm{g}, 65.6 \%)$ as indicated in Table 1. For substrates, the highest mushroom yields ( 891.25 $\mathrm{g} / \mathrm{g})$ and $\mathrm{BE}(84.3 \%)$ were obtained from rice straws and were not significantly different from banana leaves
$(778.06 \mathrm{~g} / \mathrm{g}, 74.0 \%)$ (Table 2). Finally, significant differences $(p \leq 0.05)$ in substrates on solid content of oyster mushroom were observed (Table 2). Mushrooms produced from banana leaves had highest solids contents $(9.70 \%)$ when compared to the other substrate types. However, the mushroom solids produced from banana leaves were not significantly $(p \leq 0.05)$ different from solids obtained from rice straws $(9.45 \%)$. The lowest solids $(9.20 \%)$ occurred in mushrooms produced on maize cobs and were not significantly different $(p \leq 0.05)$ from rice straws.

Table 1: Mean yield, percentage biological efficiency and mushroom size of $P$. ostreatus grown on various substrate containers

\begin{tabular}{lrrr}
\hline Substrate container & Yield $(\mathbf{g} / \mathbf{g})^{\mathrm{a}}$ & BE (\%) $)^{\mathrm{ab}}$ & \multicolumn{2}{c}{ Size $(\mathbf{g})^{\mathrm{a}}$} \\
\hline Hanging clear plastic bags & $817.83 \mathrm{a}$ & $77.7 \mathrm{a}$ & $10.2 \mathrm{a}$ \\
Re-usable substrate containers (Visado) & $694.58 \mathrm{ab}$ & $65.6 \mathrm{ab}$ & $11.2 \mathrm{a}$ \\
Coloured plastic bags (Rambo) & $668.33 \mathrm{bc}$ & $63.1 \mathrm{bc}$ & $11.4 \mathrm{a}$ \\
Shelved clear plastic bags (Vipete) & $523.75 \mathrm{c}$ & $49.4 \mathrm{c}$ & $10.8 \mathrm{a}$
\end{tabular}

aMeans within a column followed by the same letter are not significantly different at $p \leq 0.05$ according to Fisher's LSD; values are means of four replicates

b\% $\mathrm{BE}=(\mathrm{g}$ fresh mushrooms $/ \mathrm{g}$ dry substrate $) \times 100$ 

usable substrate containers and comparison of mineral content with leafy vegetables.

Table 2: Mean yield, percentage biological efficiency, size and mushroom solids content of $P$. ostreatus grown on three types of substrates

\begin{tabular}{|c|c|c|c|c|}
\hline Substrate type & Yield $(g / g)^{a}$ & $\mathrm{BE}(\%)^{\mathrm{ab}}$ & Size $(g)^{a}$ & Solids (\%) ${ }^{a}$ \\
\hline Banana leaves & $778.06 a$ & $74.0 \mathrm{a}$ & $10.4 a$ & $9.70 \mathrm{a}$ \\
\hline Rice straws & $891.25 a$ & $84.3 a$ & $10.8 \mathrm{a}$ & $9.45 a b$ \\
\hline Maize cobs & $357.81 b$ & $33.5 b$ & $11.4 \mathrm{a}$ & $9.20 \mathrm{~b}$ \\
\hline
\end{tabular}

aMeans within a column followed by the same letter are not significantly different at $p \leq 0.05$ according to Fisher's LSD; values are means of four replicates

$\mathrm{b} \% \mathrm{BE}=(\mathrm{g}$ fresh mushrooms $/ \mathrm{g}$ dry substrate $) \times 100$

Comparison of mineral content of oyster mushroom to commonly used vegetables: Significant differences $(p \leq 0.05)$ were observed on mineral contents of mushroom grown on various substrates and those of leafy vegetables. Significantly higher Fe content were from amaranth $(439.8 \mathrm{mg} / \mathrm{kg})$ followed by cassava leaves $(362.0 \mathrm{mg} / \mathrm{kg}$ ) (Fig. 5). The least Fe content was from oyster mushrooms (49.7 $\mathrm{mg} / \mathrm{kg}$ ) produced from Leucaena leucocophala substrate. Significantly higher $\mathrm{Zn}$ content were from mushrooms produced from rice straws substrate (113.5 $\mathrm{mg} / \mathrm{kg}$ ) followed by mushrooms produced from maize cobs (100.9 mg/kg) substrate (Fig. 5).

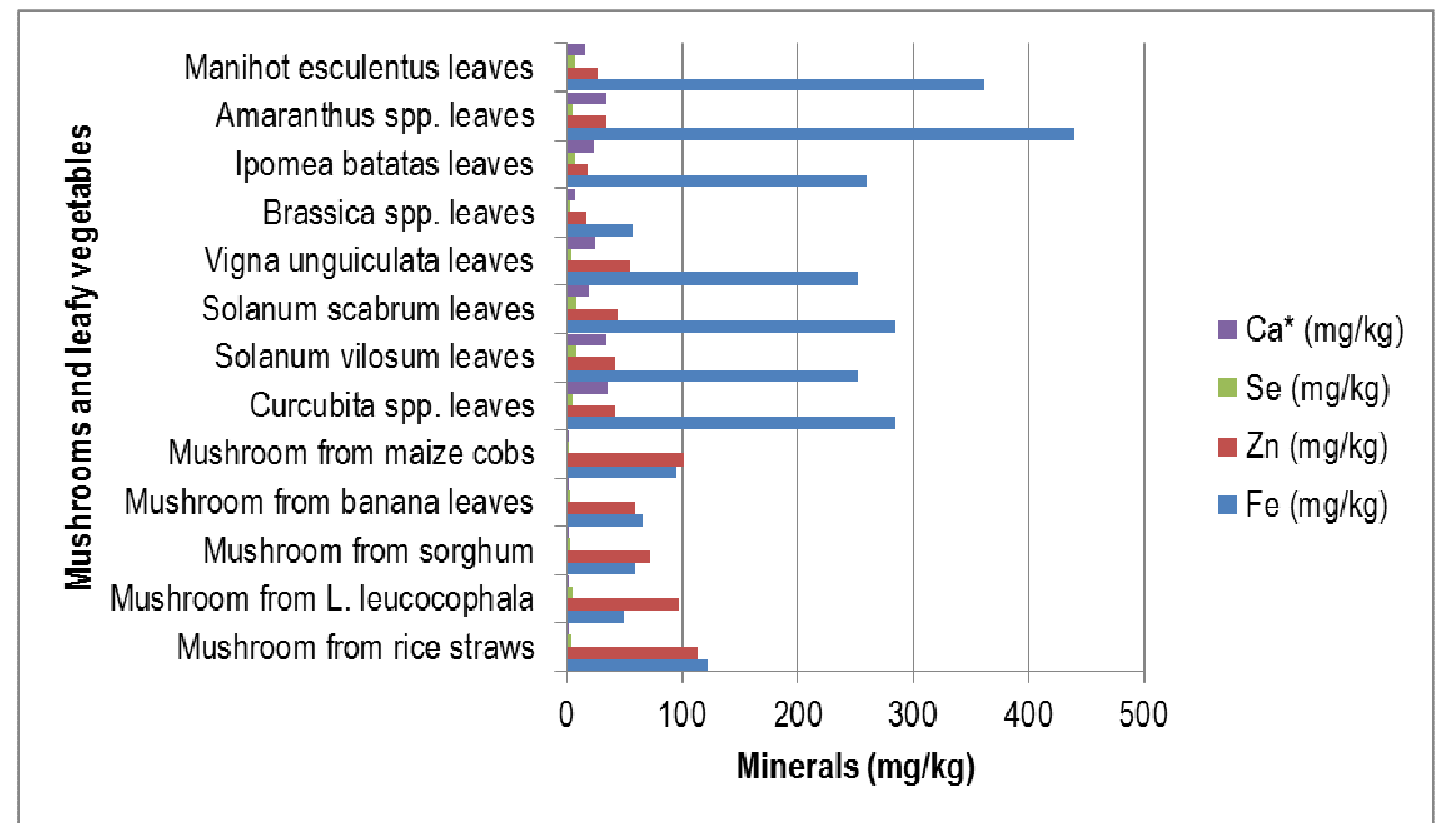

Figure 5: Mineral content of mushrooms and leafy vegetables

The least $\mathrm{Zn}$ content was from cabbage $(16.3 \mathrm{mg} / \mathrm{kg})$. Significantly, higher Se content was from narrow-leaved and broad-leaved night shades $(8.0 \mathrm{gm} / \mathrm{kg})$ followed by cassava leaves and sweet potato leaves $(7.0 \mathrm{mg} / \mathrm{kg})$. The least Se content was from oyster mushrooms (1.0 $\mathrm{mg} / \mathrm{kg}$ ) produced from maize cobs substrate. Significantly higher $\mathrm{Ca}$ content were from pumpkin leaves $(35.50 \mathrm{~g} / \mathrm{kg})$ followed by amaranth leaves (34.6 $\mathrm{g} / \mathrm{kg}$ ). The least $\mathrm{Ca}$ content was from oyster mushrooms $(0.93 \mathrm{~g} / \mathrm{kg})$ produced from banana leaves substrate. Calcium content of mushrooms from any type of substrate was not significantly different and was the lowest ranging from $1.14 \mathrm{~g} / \mathrm{kg}$ to $0.93 \mathrm{~g} / \mathrm{kg}$ (Fig. 5). 
Mamiro et al. J. Appl. Biosci. 2014. Oyster mushroom (Pleurotus spp.) Cultivation technique using reusable substrate containers and comparison of mineral content with leafy vegetables.

\section{DISCUSSION}

Effects of substrate types and substrate containers on yield, biological efficiency, size and solid content of oyster mushroom: Pleurotus spp. is produced commercially and at small scale on plastic bag substrate containers (Royse, 2003; Chang \& Quimio, 1982). Although different modifications and arrangement in the growing rooms for substrate containers has been applied, no grower has successfully eliminated the use of disposable plastic bags as substrate containers in small-scale oyster mushroom production. A number of substrate containers used in the production of oyster mushrooms has have been described by Kurtzman (2006). They include such substrate containers as open straw bales, trays of various descriptions, plastic bags and plastic tubs that cannot be re-used. In Japan, re-usable bottle in the production of oyster mushroom is common and is becoming popular in the United States of America (Royce, 2003). This study has shown that it is possible to produce oyster mushrooms by using RSC for fructification and therefore successfully eliminate the use of disposable plastic bags. While yields obtained from RSC were not as high as those obtained from hanging clear plastic bags were, they were significantly higher than those obtained from coloured plastic bags and shelved clear plastic bags. The study results show that it is possible to obtain substantial oyster mushroom yields by using RSC. Re-usable substrate containers used in our experiment were locally manufactured $5 \mathrm{~L}$ plastic bucket modified by researchers to be suitable RSC without manufactures' specification for use in oyster mushroom cultivation. Although results from this study are promising, more work is required by manufacturers to obtain heat-resistant RSC specifically to be used in oyster mushroom cultivation and frequent usage. Re-usable substrate containers are ideal technology for small-scale oyster mushroom producers in the developing countries where re-cycling of plastic materials is not in place. On the other hand, the results are based on relatively small containers and may not reflect the experiences of growers who use large plastic bags that contain more than $3 \mathrm{~kg}$ of substrate on w/w basis and bales in small-scale oyster mushroom production industry in the developed countries. Threekilogram RSC are ideal in the warm tropics to avoid heating up of substrate at the centre, and this is the reason for the selected container size in our study. The use of RSC may also help to reduce the problem of environmental contamination or degradation by plastic bag waste disposal. Oyster mushrooms harvested from banana leaves had the highest solids while those from maize cobs had the lowest. The solids content reported in this study were slightly higher if compared to those of Agaricus bisporus ranged from 7.2-8.7\% (Weil et al., $2004 ; 2006$ ) and $7.5-8.6 \%$ (Schroeder \& Schisler, 1981). Oyster mushrooms may contain more nutrients other than those reported in this study, which might have contributed to their slightly higher solids content.

Comparison of mineral content of oyster mushroom to commonly used vegetables: Overall Fe from common vegetables except cabbages were higher than from oyster mushrooms produced from any type of substrates. The highest Fe content were from amaranth followed by cassava leaves while the least were from oyster mushrooms produced from sorghum grains followed by cabbages. This trend was closely similar to $\mathrm{Ca}$ and $\mathrm{Se}$ contents. However, $\mathrm{Ca}$ contents for oyster mushrooms from any substrate were similar and were $1140 \mathrm{mg} / \mathrm{kg}$ from rice straws, $1030 \mathrm{mg} / \mathrm{kg}$ from sorghum grains, $930 \mathrm{mg} / \mathrm{kg}$ from banana leaves and $1100 \mathrm{mg} / \mathrm{kg}$ from maize cobs. The highest Se content were from narrow-leaved African night shade and broad-leaved African night shade, and had the same value $(8.0 \mathrm{mg} / \mathrm{kg})$ while the least $(2.7 \mathrm{mg} / \mathrm{kg})$ were from oyster mushrooms produced from sorghum grains and banana leaves substrates. Overall $\mathrm{Zn}$ from oyster mushrooms was higher regardless of substrate types than from common vegetables. Cabbages had the least zinc content. The highest $\mathrm{Zn}$ content was from oyster mushrooms produced from rice straws followed by oyster mushrooms produced from maize cobs. Compared with vegetables, oyster mushrooms produced from any substrate were found to be good sources of $\mathrm{Zn}$ in ranges of $113.5-59.8 \mathrm{mg} / \mathrm{kg}$ while in vegetables the range $54.1-16.3 \mathrm{mg} / \mathrm{kg}$. This is in agreement with the study by Mattila et al. (2001) where they also found that compared with the vegetables, both white and brown button mushrooms (Agaricus bisporus), Lentinus edodes, and Pleurotus ostreatus were good source of many mineral elements $(K, P, Z n$, and $\mathrm{Cu}$ ). The mineral content of the basidiomata of Pleurotus ostreatus were found to be different (Vetter et al., 2005) on different substrates (Bisaria et al., 1987b). Iron was significantly higher in mushrooms produced from rice straw substrate followed by maize cobs substrate, then banana leaves, sorghum grains and finally Leucaena leucicophala. Variation of other mineral contents in the fruiting bodies ( $\mathrm{Zn}, \mathrm{Se}, \mathrm{Ca}$ ) was also found to vary from substrate types. Vetter et al., (2005) obtained different mineral compositions in 

usable substrate containers and comparison of mineral content with leafy vegetables.

Agaricus bisporus, Pleurotus ostreatus and Lentinus edodes produced from different types of substrates. We were able to demonstrate the utilization of RSC to produce oyster mushrooms. The utilization of RSC conserve environment from dispose of plastic bags which are non-biodegradable and if burned may cause ill-health effect to the human. Additional research is needed to specify quality of material to be used in the manufacture of RSC and specifications to suit cultivation of oyster mushrooms. It was evident also that consumption of oyster mushrooms in combination with other vegetables would complement availability of various essential dietary elements. However, additional work is required to explore more range of elements and more vegetable species.

\section{ACKNOWLEDGEMENT}

The authors wish to thank Helen Mbije, Jackson Nahson, Pastory Salvatory and Veneranda Pius of Department of Crop Science and Production for technical assistance.

\section{REFERENCES}

Alcock RE and Jones KC, 1996. Dioxins in the environment: a review of trend data. Environ Sci Technol 30(11):3133-3143.

Andersen $G$ and Knapp M, 1993. Dioxin factories: A study of the creation of dioxins and other organochlorines from the production of PVC. Amsterdam: Greenpeace International. Pp 19.

AOAC, 1995. Official methods of analysis. Association of Official Analytical Chemists methods, AOAC $16^{\text {th }}$ Edition Nos. 963.13, 968.08, 970.12, 915.03, 920.87. Washington, D.C.

Bisaria R, Madan M, Bisaria VS, 1987b. Mineral content of mushroom Pleurotus sajor-caju cultivated on different agro residues. Mushroom Journal for the Tropics 7:53-60.

Bisaria R, Madan M, Vasudevan P, Bisaria VS, 1989. Effect of variation in size of containers on yield of Pleurotus sajor-caju. Biological Wastes 30(2):149-152.

Chang ST and Miles PG, 1989. Edible Mushrooms and their cultivation, Florida: CRC press.

Chang ST and Quimio TH, 1982. Tropical Mushrooms, biology, nature and cultivation methods. Hong Kong. The Chinese University Press.

FAO, 1990. Technical guidelines for mushroom growing in the tropics. Food and Agriculture Organization of the United Nations, Rome, pp 154 ISBN 92-5-103026-X.

Kuehl RO, 2000. Design of experiments: statistical principles of research design and analysis, 2nd edn. Duxbury Press. Pacific Grove, CA, $666 \mathrm{pp}$.

Kurtzman R, 2006. Oyster Mushroom Cultivation. Chapter 3, 27-40. www.oystermushrooms.net/chap3.pdf. Accessed 30th Jan., 2014.
Mamiro DP and Mamiro PS, 2011. Yield and mushroom size of Pleurotus ostreatus grown on rice straw basal substrate mixed and supplemented with various crop residues. Journal of Animal \& Plant Sciences 10(1):1211-1218.

Mattila P, Könkö K, Eurola M, Pihlava JM, Astola J, Vahteristo L, Hietaniemi V, Kumpulainen J, Valtonen M, Piironen V, 2001. Contents of vitamins, mineral elements and some phenolic compounds in cultivated mushrooms. Journal of Agriculture and Food Chemistry 49 (5):2343-2348.

Mushworld, 2004. Mushroom Growers Handbook. Oyster mushroom cultivation. Heineart Inc. Korea. 70-189 pp.

Oei P, 2003. Mushroom cultivation with special emphasis on appropriate techniques for developing countries. Leiden. The Netherlands. 290 pp.

Rodriguez-Estrada AE and Royse DJ, 2005. Cultivation of Pleurotus eryngii in bottles. Mushroom News 53(2):10-19.

Royce DJ, 2003. Cultivation of Oyster Mushrooms. The Pennsylvania State University, College of Agricultural Science, Agricultural Research and Cooperative Extension Bulletin. Pages 111.

SAS, 2001. Statistical analysis system. SAS Institute Inc., Cary, NC, USA.

Schroeder GM and Schisler LC, 1981. Influence of compost and casing moisture on size, yield and dry weight of mushrooms. Mush. Sci. 11:495-509.

Thorntom J, 1997. Dioxin from cradle to grave. Amsterdam: Greenpeace Report ISBN 9073361-35-4. Pp 66. 
Mamiro et al. J. Appl. Biosci. 2014. Oyster mushroom (Pleurotus spp.) Cultivation technique using reusable substrate containers and comparison of mineral content with leafy vegetables.

Upadhyay RC and Sing M, 2010. Production of edible mushrooms. In: The Mycota: A comprehensive treatise on Fungi as experimental systems for basic and applied research. Industrial Applications $X .2^{\text {nd }}$ Edition. Editor: Hofrichter M.Springer. ISBN 978-3-642-11457-1. Page 85.

Vetter J, Hajdu C, Gyorfi J, Maszlaver P, 2005. Mineral composition of the cultivated mushrooms (Agaricus bisporus, Pleurotus ostreatus and Lentinus edodes. Food chemistry 50(3):277279.

Weil DA, Beelman RB, Beyer DM, 2004. Effect of adding a micronutrient-rich supplement to compost on yield and quality of Agaricus bisporus. Mush. Sci. 16:365-371.

Weil DA, Beelman RB, Beyer DM, 2006. Manganese and other additions to improve yield of Agaricus bisporus. Bioresour. Technol. 97:1012-1017. 